\title{
Feasibility study of coconut coir dust briquette
}

\author{
K. K. Saha ${ }^{1 *}$, M. M. Hossain ${ }^{2}$, M. R. Ali ${ }^{2}$ and M. M. Alam ${ }^{2}$ \\ ${ }^{1}$ Department of Farm Power and Machinery, Sylhet Agricultural University, Sylhet-3100, Bangladesh and \\ ${ }^{2}$ Department of Farm Power and Machinery, Bangladesh Agricultural University, Mymensingh-2202, Bangladesh, \\ *E-mail: khokan12ag.eng@gmail.com
}

\begin{abstract}
This research work was conducted on economic feasibility of briquette made of coconut coir dust mixed with rice husk at different ratio. This study sought to assess the physical properties and calorific value of briquette and to establish the demand and willingness of potential users to substitute rice husk briquette and firewood. It was observed that briquette made from mixed coconut coir dust and rice husk at the ratio of 1:2 and 1:1 had desirable properties as compared to rice husk briquette. The percent of shatter indices, density, percent of resistance to water penetration, degree of densification and calorific value of briquette of mixing ratio $1: 2$ were found $99.75,1.52 \mathrm{gm} / \mathrm{cc}$, $87.5,11.35$ and $4043 \mathrm{kcal} / \mathrm{kg}$ and of mixing ratio $1: 1$ were found $99.82,1.48 \mathrm{gm} / \mathrm{cc}, 87.5,10.84$ and $3657 \mathrm{kcal} / \mathrm{kg}$, respectively. In case of rice husk briquette, the above values were $99.21,1.40 \mathrm{gm} / \mathrm{cc}, 75,10.66$ and $3537 \mathrm{kcal} / \mathrm{kg}$, respectively. The production costs of mixing ratio $1: 2$ and $1: 1$ were $3.27 \mathrm{Tk} / \mathrm{kg}$ and $3.10 \mathrm{Tk} / \mathrm{kg}$, respectively which were lower than that of rice husk briquette. In partial budget, the substitution propositions among the selected briquettes indicated that coconut coir dust briquette of mixing ratio 1:1 appeared as the most impressive one.
\end{abstract}

Keywords: Briquette, Coconut coir dust, Shatter index, Cost analysis

\section{Introduction}

In Bangladesh briquetting process is carried out in the screw press type briquetting machine on which mainly briquetting of rice husk are commercially produced. But to become dependent on a single raw material will cause hamper when there is scarcity of that material in the market. Thus, to take the full advantage of the locally available raw material, different mixtures of those are considered for producing briquette. With the passes of time, demand of rice husk is increased. Large amount of rice husk is used in fish feeds, poultry feeds, poultry rearing, livestock husbandry and steaming of rice mill boiler. Due to insufficient supply of rice husk for briquetting, many briquetting machines are now out of production all over Bangladesh.

There are about1200 numbers of briquette machines in Bangladesh (Alam et al., 2011). Among these, only 906 numbers briquette machine are running throughout the country and all machines are the heated die screw extruder type. There are 102 numbers briquette machine remain in Khulna region (Alam et al., 2011).

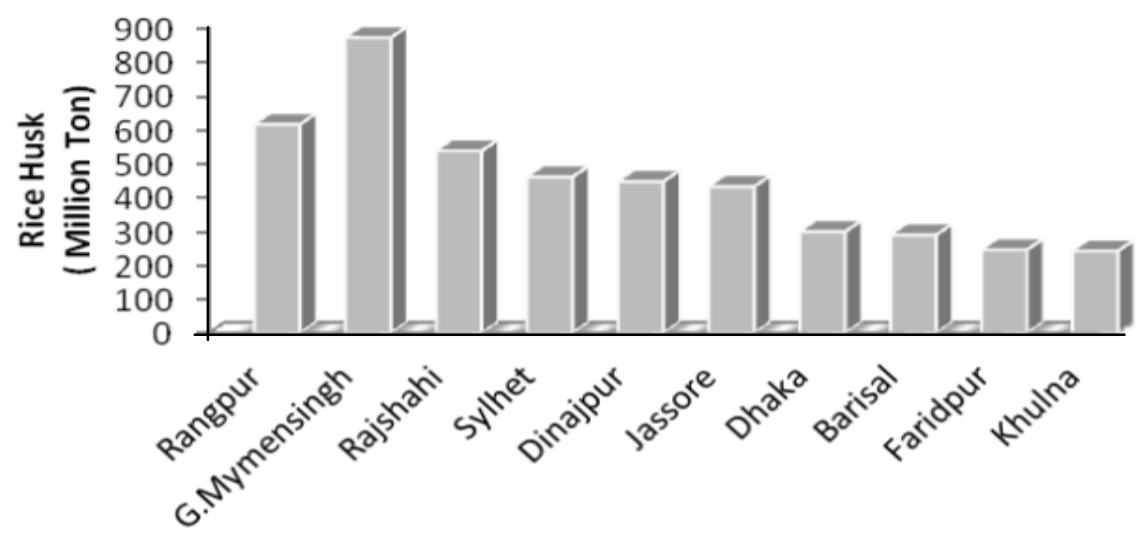

Region

Fig. 1. Rice husk production in the financial year 2009-2010 in Bangladesh (Alam et al, 2011) 
The production of rice husk at Khulna division is lowest in Bangladesh (Fig.1) and no increasing trend of rice husk production observed in last few years. So it was found that the large number of briquette machine was remaining idle for the scarcity of rice husk in that region.

Bangladesh has about 2800 ha of coconut land and the average annual coconut production is about $316000 M T$ (BBS, 2009). The principal byproducts of coconut oil industries are coconut husk and coconut shell. Coconut shell is used for making mosquitoes coils and it is also a good source of charcoal. Coconut husk is used in coconut fiber industries for extracting fiber which is usually used in making ropes, mattress, household products like doormats, floor mats, brushes, floor tiles, sacking, twine, etc. The waste of coconut fiber industries is coir dust which is obtained after extracting fiber from coconut husk and has a very limited usage. In Bangladesh, a small amount of coir dust is used for making bio-compost and most of the coir dust is left as waste product. So, briquetting of coconut coir dust has a great prospect in Bangladesh.

The main goal of the study is to assess the economic viability of the coconut coir dust briquette. This coconut coir dust may replace the shortage of rice husk. Coconut coir dust can not itself form the briquette like rice husk. Coconut coir dust mixed with rice husk can form briquette. But physical properties and acceptance to the user needs to be studied. Therefore this research has been undertaken with the following objectives (i) to determine the physical properties and calorific value of coconut coir dust briquette and (ii) to determine the economic feasibility of the briquette.

\section{Materials and Methods}

\section{Sampling of raw material}

The sample was prepared for briquette formation using the following ratio of coconut coir dust and rice husk. Then the coconut coir dust and rice husk were thoroughly mixed by hand until a uniform mixture was obtained as shown in Table1.

Table 1. Mixing ratio (by weight) of coconut coir dust and rice husk to produce briquette

\begin{tabular}{|c|c|c|}
\hline Sample & Coconut coir dust & Rice husk \\
\hline 1 & 1 & 2 \\
\hline 2 & 0 & 1 \\
\hline 3 & 2 & 1 \\
\hline 4 & 1 & 1 \\
\hline 5 & 3 & 1 \\
\hline
\end{tabular}

\section{Capacity of briquette machine}

Overall capacity of coconut coir dust and rice husk briquette formation in briquette machine was determined during manufacturing of briquette. The weight of raw material before briquetting was recorded. The capacity of coconut coir dust briquette by following formula

Capacity $\left(\frac{\mathrm{kg}}{\mathrm{hr}}\right)=\frac{\mathrm{W}}{\mathrm{T}} \times \mathrm{T}$

where, $W=$ weight of produced briquettes, $\mathrm{kg}$ and $T=$ time, $\min$

\section{Analysis of briquetted fuel}

Physical properties of coconut coir dust briquette: Physical properties (Density, shatter indices and resistance to water penetration) were determined in the Department of Farm Power and Machinery, Bangladesh Agricultural University, Mymensingh. 
Measurement of briquette density: The cross sectional area of the samples was calculated using the following formula.

Cross-sectional area, $A=\frac{\pi\left(D_{0}^{2}-D_{i}^{2}\right)}{4} \mathrm{~cm}^{2}$

where, $D_{0}=$ outside diameter of briquette, $\mathrm{cm}, D \mathrm{i}=$ inside diameter of briquette, $\mathrm{cm}$.

The density of the briquettes was calculated by using the following equation (Islam, et al. 2014).

Density, $\rho=\frac{\mathrm{W}}{\mathrm{AL}}$

where, $\rho=$ density $(\mathrm{g} / \mathrm{cc}), W=$ weight $(\mathrm{gm}), A=$ cross-sectional area of the briquette $\left(\mathrm{cm}^{2}\right)$ and $L=$ length $(\mathrm{cm})$.

Shatter indices: Shatter indices were used for determining the hardness of briquettes. The briquette with known weight and length was dropped on RCC floor or concrete floor from the height of one meter. The weight of disintegrated briquette and its size was noted down. The percent loss of material was calculated. The shatter resistance of the briquettes was calculated by using following formula (Ghorpade, 2006).

$$
\% \text { Weight loss }=\frac{W_{1}-W_{2}}{W_{1}} \times 100
$$

$\%$ Shatter resistance $=100-\%$ Weight loss where, $W_{1}=$ Weight of briquette before shattering and $W_{2}=$ Weight of briquette after shattering.

\section{Resistance to water penetration}

It is the measure of percentage of water absorbed by a briquette when immersed in water. Each briquette $(8 \mathrm{gm})$ was immersed in $25 \mathrm{ml}$ of water at $27^{\circ} \mathrm{C}$ for $30 \mathrm{sec}$. The percent water gain was then recorded and calculated by using following formula (Tayade, 2009).

$\%$ of water gained by briquette $=\frac{w_{2}-w_{1}}{w_{1}} \times 100$

$\%$ Resistance to water penetration $=100-\%$ water gain

where, $W_{1}=$ Initial weight of briquette and $W_{2}=$ Final weight of briquette .

\section{Thermal properties of coco coir dust briquette}

Calorific value: The calorific value of briquetted fuel was determined by using bomb calorimeter. The calorific values of different briquette samples were determined by using following formula (Dara, 1999).

Calorific value $\left(\frac{\mathrm{kcal}}{\mathrm{kg}}\right)=\frac{(\mathrm{W}+\mathrm{w}) \times\left(\mathrm{T}_{1}-\mathrm{T}_{2}\right)}{\mathrm{X}}$

where, $W=$ weight of water in calorimeter $(\mathrm{kg}), w=$ water equivalent of apparatus $(\mathrm{kg}), T_{1}=$ initial temperature of water $\left({ }^{0} \mathrm{C}\right), T_{2}=$ final temperature of water $\left({ }^{0} \mathrm{C}\right), X=$ weight of fuel sample taken $(\mathrm{kg})$.

\section{Cost analysis}

\section{Fixed costs}

Annual depreciation: There are many methods for calculating depreciation. In this study the "StraightLine" method is used. Depreciation (D) was determined by following equation:

Depreciation, $\mathrm{D}=\frac{\mathrm{P}-\mathrm{S}}{\mathrm{L}}$

where, $D=$ depreciation (Tk/yr), $P=$ purchase price of machine (Tk). $S=$ salvage value of machine (Tk), $L$ $=$ useful life time $(\mathrm{yr})$. In this study, salvage value is assumed as 10 percents of purchase price. 
Interest on investment: Interest on investment $(I)$ was determined by following equation:

$\mathrm{I}=\frac{\mathrm{P}+\mathrm{S}}{2} \times \mathrm{i}$

where, $I=$ interest on investment (Tk/yr), $P=$ purchase price of machine (Tk), $S=$ salvage value (Tk), and $i$ $=$ interest rate, decimal (consider $10 \%$ per years).

Cost of housing $(\mathrm{CH})$ : Cost of housing $(\mathrm{CH})$ was calculated by multiplying house rent per month by 12 .

Electricity demand and machine installation cost: Electricity demand and machine installation cost (EMI) were recorded from briquette machine owner. EMI was calculated by following formula:

$E M I=\left(\frac{T k}{y r}\right)=\frac{D_{i}(1+i)^{N}-D_{i}}{10}$

where, $E M I=$ electricity demand and machine installation cost $(\mathrm{Tk} / \mathrm{yr}), D_{i}=$ machine installation cost plus electric demand cost (Tk), $N=$ machine life $(\mathrm{yr}), i=$ interest rate $(10 \%)$.

\section{Total fixed cost (Tk/hr)}

Total fixed cost $(\mathrm{Tk} / \mathrm{hr})$ was calculated by following equations:

Total fixed cost $(\mathrm{Tk} / \mathrm{yr})=\mathrm{D}+\mathrm{I}+\mathrm{CH}+\mathrm{EMl}$

Total fixed cost $=\left(\frac{\mathrm{Tk}}{\mathrm{yr}}\right)=\frac{\text { Total fixed cost }\left(\frac{\mathrm{Tk}}{\mathrm{yr}}\right)}{\text { annual use of machine in } \mathrm{hrs}\left(\frac{\mathrm{hr}}{\mathrm{yr}}\right)}$

Variable cost: Total variable cost $(\mathrm{Tk} / \mathrm{hr})=$ repair and maintenance cost of screw $(\mathrm{Tk} / \mathrm{hr})+\operatorname{cost}$ of die heater $(T k / h r)+$ electricity cost $(T k / h r)+$ labor cost $(T k / h r)+$ staff salary $(T k / h r)+$ cost of rice husk $(T k / h r)+$ transportation cost of coconut coir dust (Tk/hr).

Total production cost of coconut coir dust briquette (Tk/kg): Total production cost of coconut coir dust briquette is the sum of hourly fixed cost and variable cost i.e. Production cost $(\mathrm{Tk} / \mathrm{hr})=$ Fixed cost $(T k / h r)+$ Variable cost $(T k / h r)$.

Production cost $(\mathrm{Tk} . / \mathrm{kg})=$ Production cost $(\mathrm{Tk} / \mathrm{hr}) /$ production rate of briquette $(\mathrm{kg} / \mathrm{hr})$.

Benefit cost ratio: Benefit cost $(B / C)$ ratio was defined as the ratio of gross revenue to production cost.

$\frac{\mathrm{B}}{\mathrm{C}}$ ratio $=\frac{\text { Gross revenue }}{\text { Productioncost }}$

Calculation for gross margin and net margin: The Gross Margin was calculated as Gross Output less total variable cost and Net Margin (NM) was calculated as Gross Margin less fixed costs.

Gross revenue $=$ Selling rate of briquette per $\mathrm{kg}$

Gross Margin = [Gross Output] $-[$ Total variable cost $(\mathrm{Tk} / \mathrm{hr}) /$ production rate of briquette $(\mathrm{kg} / \mathrm{hr})]$

Net Margin = [Gross Margin] - [Fixed cost $(\mathrm{Tk} / \mathrm{hr}) /$ production rate of briquette $(\mathrm{kg} / \mathrm{hr})]$

Partial budget calculation

\begin{tabular}{ll}
\hline Cost of change & Benefit of change \\
\hline GM lost & Extra $\mathrm{GM}:$ \\
Expected $\mathrm{GM}$ of the existing system & Expected $\mathrm{GM}$ of the existing system \\
Extra fixed costs: & Fixed cost saved: \\
Estimated new fixed cost & Estimated reduction of fixed cost \\
\hline Total costs $(\mathrm{X})$ & Total benefits $(\mathrm{Y})$ \\
\hline Net grain $(\mathrm{Y}>\mathrm{X})$ & Net loss $(\mathrm{X}>\mathrm{Y})$ \\
\hline
\end{tabular}




\section{Results and Discussion}

\section{Physical properties}

Density: The density of briquette for coconut coir dust and rice husk mixing ratio at 1:1(sample 4) and 1:2 (sample1) were $1.48 \mathrm{gm} / \mathrm{cc}$ and $1.52 \mathrm{gm} / \mathrm{cc}$, respectively which is shown in Fig. 2. The density of briquette for coconut coir dust and rice husk ratio of 3:1 (sample 5) and 2:1 (sample 3) were $1.32 \mathrm{gm} / \mathrm{cc}$ and $1.34 \mathrm{gm} / \mathrm{cc}$, respectively. Whereas, the density of only rice husk briquette (sample 2) was found 1.40 $\mathrm{gm} / \mathrm{cc}$. The density of the briquette sample 1 and sample 4 is higher than rice husk briquettes (sample 2). It indicates that briquette sample 1 and sample 4 more compact than rice husk briquettes.

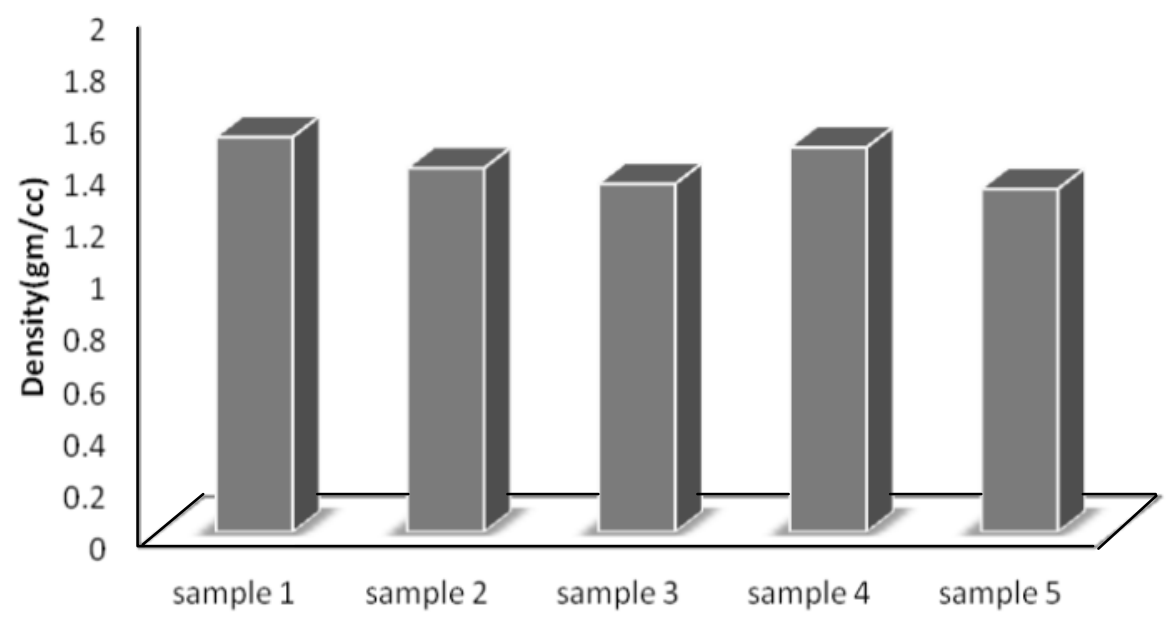

Fig. 2. Density of briquetted fuel

Shatter indices: According to Table 2, all coconut coir dust briquette except mixing ratio 3:1 (i.e. with more coco dust) are harder and less disintegration during transportation.

Table 2. Shatters indices of briquette

\begin{tabular}{|c|c|c|}
\hline Sample & Coconut coir dust : Rice husk & Shatter indices \\
\hline Sample1 & $1: 2$ & 99.75 \\
\hline Sample2 & $0: 1$ & 99.21 \\
\hline Sample3 & $2: 1$ & 99.06 \\
\hline Sample4 & $1: 1$ & 99.82 \\
\hline Sample5 & $3: 1$ & 95.52 \\
\hline
\end{tabular}

\section{Resistance to water penetration}

From the result (Fig. 3) of resistance to water penetration, it is observed that briquette from sample 5 was least water resistance ( 25 percent) compared to highest water resistance of 87.3 percent for briquette from coconut coir dust and rice husk mixing ratio1:2 and 1:1. It indicate that short-term exposure to rain or high humidity conditions during transportation and storage could not adversely affect the quality of the briquette made with mixing ratio $1: 2$ and 1:1 than rice husk briquette. 


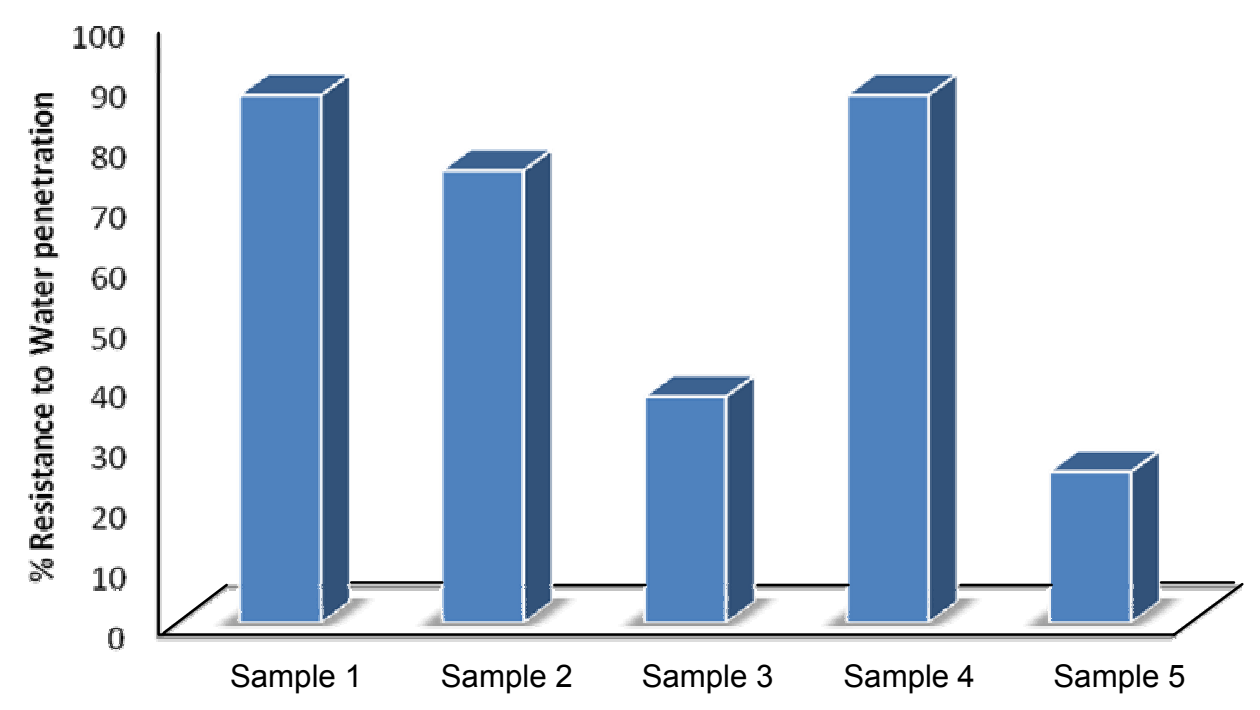

Fig. 3. Resistance to water penetration of briquettes

\section{Thermal property}

Calorific value: The calorific value of briquette fuel shows that the calorific value for mixing ratio $1: 2$ was found to be $4043 \mathrm{kcal} / \mathrm{kg}$ and briquette for the ratio $3: 1$ has least calorific value $3395 \mathrm{kcal} / \mathrm{kg}$ whereas the calorific value of rice husk briquettes was found $3537 \mathrm{kcal} / \mathrm{kg}$. The comparative result of calorific value is shown in Fig.4

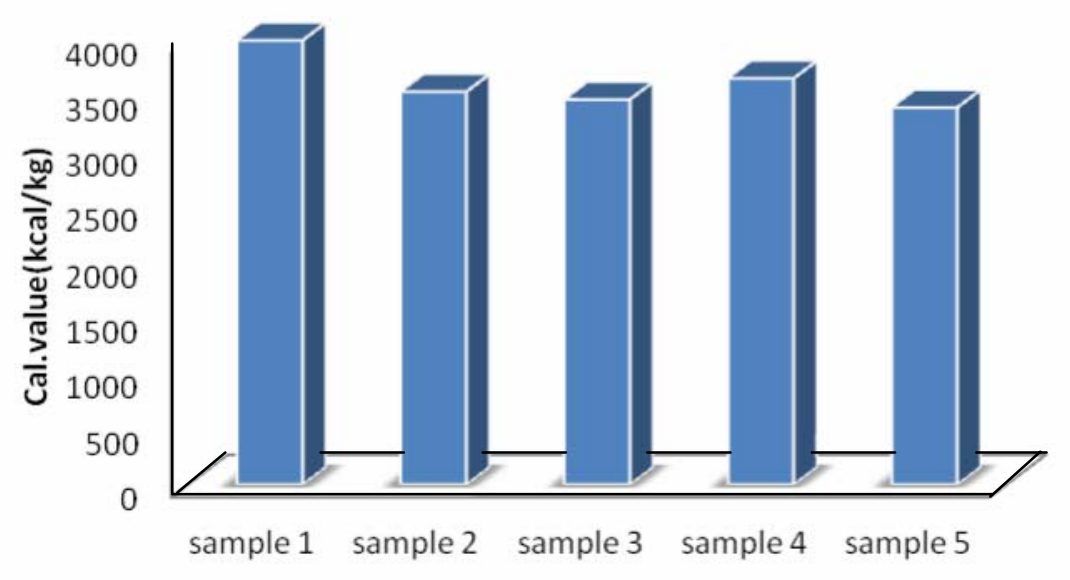

Fig. 4. Calorific value of briquette

\section{Cost analysis of coconut coir dust briquette production}

The cost analysis of the product (rice husk briquette and coconut coir dust briquette) and the briquetting system were done on the basis of one hour capacity of the briquetting machine and the present market price of the raw materials. All analysis was calculated in local currency Taka. 


\section{Consideration for cost analysis}

Considering 25 days operation per month and 300 days/yr and 10 hours per day

The total cost of one complete briquetting machine $=$ Tk. 70,000

Economic life of the machine $=10$ years

Interest rate $=10 \%$ annually

Economic life of a screw $=100$ hrs (at least 15 times repair)

Initial cost of new screw $=$ Tk. 800

Repairing cost of screw $=$ Tk. 900

New die heater charge $=$ Tk. 1200

Economic life of a die heater $=500 \mathrm{hrs}$

Unit price of electricity per $\mathrm{KWh}=\mathrm{Tk} .7$

Machine installation cost $=$ Tk.4000

Land cost/ rent of the shed per month $=$ Tk. 1000

Electric line demand cost per KW = Tk. 1450

Raw materials cost (rice husk) per $\mathrm{kg}=\mathrm{Tk} .2 .25$

Price of briquette per $\mathrm{kg}=\mathrm{Tk} .5$

The cost analysis was performed on the basis of above. The total production costs of sample 1 and sample 4 were Tk.3.27/kg and Tk $3.10 / \mathrm{kg}$, respectively. Whereas, the total cost of sample 2 was found Tk $3.78 / \mathrm{kg}$. The total costs of sample 3 and sample 5 were found as same Tk.3.86/kg. The total production costs of sample 1 and sample 4 were less than rice husk briquette.

According to Table 3 , the benefit cost $(B / C)$ ratio for sample1, sample 4 , sample 3 and sample 5 were found $1.52,1.61,1.29$ and 1.29 , respectively. Whereas, the $B / C$ ratio for sample 2 was 1.32 . So, the $B / C$ ratio for sample 4 was found highest among all the samples. The gross margin and net margin of sample 1and sample 4 were found as $1.80 \mathrm{Tk} / \mathrm{kg}, 1.72 \mathrm{Tk} / \mathrm{kg}$ and $1.97 \mathrm{Tk} / \mathrm{kg}$ and $1.89 \mathrm{Tk} / \mathrm{kg}$, respectively which were higher than that of sample 2 (rice husk briquette).

Table 3. Comparison of production rate and economic suitability of different raw materials used for briquette production

\begin{tabular}{|c|c|c|c|c|c|c|c|}
\hline $\begin{array}{c}\text { Sample } \\
\text { (coconut dust: } \\
\text { rice husk) }\end{array}$ & $\begin{array}{c}\text { Production } \\
\text { rate(kg/hr) }\end{array}$ & $\begin{array}{c}\text { Raw materials } \\
\text { required (kg/hr) }\end{array}$ & $\begin{array}{c}\text { Production } \\
\text { cost } \\
(\mathrm{Tk} / \mathrm{hr})\end{array}$ & $\begin{array}{c}\text { Production } \\
\text { cost (Tk/kg) }\end{array}$ & $\begin{array}{c}\text { Selling } \\
\text { price } \\
(\mathrm{Tk} / \mathrm{kg})\end{array}$ & $\begin{array}{c}\text { Selling } \\
\text { price } \\
(\mathrm{Tk} . / \mathrm{hr})\end{array}$ & $\begin{array}{c}\text { Benefit cost } \\
(\mathrm{B} / \mathrm{C}) \text { ratio }\end{array}$ \\
\hline $\begin{array}{c}\text { Sample-1 } \\
(1: 2)\end{array}$ & 110 & 122 & 360.45 & 3.27 & 5 & 550 & 1.52 \\
\hline $\begin{array}{c}\text { Sample-2 } \\
(0: 1)\end{array}$ & 120 & 132 & 453.95 & 3.78 & 5 & 600 & 1.32 \\
\hline $\begin{array}{c}\text { Sample-3 } \\
(2: 1)\end{array}$ & 65 & 85 & 250.95 & 3.86 & 5 & 325 & 1.29 \\
\hline $\begin{array}{c}\text { Sample-4 } \\
(1: 1)\end{array}$ & 100 & 112 & 310.95 & 3.10 & 5 & 500 & 1.61 \\
\hline $\begin{array}{c}\text { Sample-5 } \\
(3: 1)\end{array}$ & 60 & 80 & 231.95 & 3.86 & 5 & 300 & 1.29 \\
\hline
\end{tabular}

\section{Substitution proposition among different briquette samples}

From Table 4, the gross margin and net margin of coconut coir dust briquette mixing ratio of $1: 1$ and $1: 2$ were found higher than that of rice husk briquette. Therefore, coconut coir dust briquette of mixing ratio $1: 1,1: 2$ and rice husk briquette were selected for partial budget calculation. The gross margin and fixed cost data of different briquette samples were used in partial budget format and substitution propositions are presented in Table 4. The substitution propositions of rice husk briquette by the mixing ratio of $1: 1$ and 1:2 coconut coir dust briquette were ended with net gain i.e. coconut coir dust briquette of mixing ratio $1: 1$ was found economically superior over coconut coir dust briquette of mixing ratio $1: 2$ and rice husk briquette. The substitution propositions among the selected briquettes indicated that coconut coir dust briquette of mixing ratio 1:1 appeared as the most impressive one. 
Table 4. Substitution proposition of different briquette samples by partial budgeting

\begin{tabular}{|c|c|c|}
\hline Sample & $\begin{array}{c}\text { Sample 1 } \\
\text { (coco dust : rice husk=1:2) }\end{array}$ & $\begin{array}{c}\text { Sample 4 } \\
\text { (coco dust : rice husk=1:1) }\end{array}$ \\
\hline $\begin{array}{c}\text { Sample 2 } \\
\text { (Rice husk briquette) }\end{array}$ & Net gain Tk.0.52/kg & Net gain Tk.0.69/kg \\
\hline $\begin{array}{c}\text { Sample 1 } \\
\text { (coco dust : rice husk=1:2) }\end{array}$ & & Net gain Tk.0.17/kg \\
\hline
\end{tabular}

\section{Conclusion}

The briquette made of coconut coir dust mixed with rice husk at ratio 1:1and 1:2 was found better in all aspect such as density, shatter index, water penetration, degree of densification and economic analysis. The total production costs of the briquette with mixing ratio of $1: 1$ and $1: 2$ were Tk.3.10/kg, and Tk.3.27/kg, respectively. In partial budget, the substitution propositions among the selected briquettes indicated that coconut coir dust briquette of mixing ratio 1:1 appeared as the most impressive one.

\section{References}

Alam, M., Islam, M., Hasan, M. and Siddique, T.A. 2011. A study on biomass briquette in Bangladesh. Proc. Int. Conf. Mech. Eng., (ICME), 18-20 December, 2011, Dhaka, Bangladesh. pp.1-6.

BBS, 2009. Statistical Yearbook of Bangladesh. Bangladesh Bureau of Statistics. Statistics Division, Ministry of Planning, Govt. of the People's Republic of Bangladesh. pp.147-153

Dara, S.S. 1999. A textbook on Experiments and Calculations in Engineering Chemistry. S. Chand publication, New Delhi.pp.70-72.

Ghorpade, S.S. and Moule, A.P. 2006. Performance evaluation of deoiled cashew shell waste for fuel properties in bri-quetted form. B.Tech. Thesis, Dapoli. pp- 15.

Islam, M.H., Hossain, M.M. and Momin, M.A. 2014. Development of briquette from coir dust and rice husk blend: An alternative energy source. Int. J. Renewable Energy Development, 3(2):119-123

Tayade, S.R. 2009. Evaluation of different biomass briquettes making for gasifier. M.Tech. Thesis, Akola. pp.34-35. 